\title{
Distyly and floral morphology of Psychotria cephalophora (Rubiaceae) on the oceanic Lanyu (Orchid) Island, Taiwan
}

\author{
Kenta Watanabe ${ }^{1 *}$, T Y Aleck Yang ${ }^{2,3}$, Chihiro Nishihara ${ }^{4}$, Tai-Liang Huang ${ }^{2}$, Koh Nakamura ${ }^{5}$, Ching-I Peng ${ }^{6}$
} and Takashi Sugawara ${ }^{7}$

\begin{abstract}
Background: Psychotria cephalophora Merr. (Rubiaceae), a shrub in oceanic islands of Taiwan and the Philippines, appears to be distylous, but distyly is usually rare on oceanic islands. To elucidate the functional breeding system of P. cephalophora can improve our understanding of plant reproductive ecology on oceanic islands.

Results: Field investigations on Lanyu (Orchid Island) off the coast of southeastern Taiwan revealed the flowers to be distylous with short (S)- and long (L)-styled morphs, with only one morph per individual. Laboratory observations revealed that both morphs had stainable pollen grains and indicated dimorphism in stigmatic papillae and pollen size. In hand pollination experiments, the pollen tubes reached the base of the style in intermorph crossing, whereas they rarely penetrated stylar tissue in intramorph crossing and selfing. Open pollinated S- and L-styled flowers produced fruit.
\end{abstract}

Conclusions: The results indicate that the breeding system of $P$. cephalophora is morphologically and functionally distylous.

Keywords: Breeding system; Distyly; Heterostyly; Lanyu; Oceanic island; Orchid Island; Pollen dimorphism; Psychotria cephalophora; Rubiaceae

\section{Background}

Psychotria L. (Rubiaceae), one of the largest genera in flowering plants, with more than 1800 species (Davis et al. 2009), occurs mainly in tropical and subtropical regions (Hamilton 1989; Nepokroeff et al. 1999; Davis et al. 2001; Sakai and Wright 2008). Within Psychotria, distyly is regarded as the ancestral breeding system (Hamilton 1990). Distyly is a genetically controlled dimorphism reported from 26 angiosperm families (Naiki 2012). In distylous species, populations are composed of two distinct floral morphs: long (L) -styled morph with stigmas exceeding the anthers and short (S)-styled morph with anthers exceeding the stigmas. Between the two morphs male and female organs are usually at the reciprocal height (Ganders 1979;

\footnotetext{
* Correspondence: kenta-w@okinawa-ct.ac.jp

1'Okinawa National College of Technology, 905 Henoko, Nago, Okinawa

905-2192, Japan

Full list of author information is available at the end of the article
}

Barrett et al. 2000). This is a mechanism to promote animal-mediated cross-pollination.

Four species of Psychotria: three shrubs P. cephalophora, $P$. manillensis, and $P$. rubra, and a woody climber P. serpens are in Taiwan (Yang 1998b). Psychotria cephalophora occurs only on Lanyu (Orchid Island) (Yang 1998b) and Lutao (Green Island) off the coast of southeastern Taiwan (Chen and Lu 2008); P. manillensis occurs only on Lanyu, Lutao (Yang 1998b) and Kuei-Shan Tao (Turtle Island) off the coast of northeastern Taiwan (Tsai 2009); P. rubra occurs on Taiwan Island and adjacent islands, including Lutao, but not on Lanyu; P. serpens occurs on Taiwan Island and adjacent islands including Lanyu. Psychotria serpens is distylous (Yang 1998b; Sugawara et al. 2013); P. rubra is dioecious (Yang 1998b; Watanabe et al. 2014b); and P. manillensis is 
monoecious (Watanabe et al. in preparation). There has been no study of the breeding system in P. cephalophora, except that Yang et al. (1999) mentioned it to be morphologically heterostylous without detailed description. The reproductive nature of $P$. cephalophora is left to be explored.

The circumscription of Psychotria cephalophora has been controversial. Psychotria cephalophora was described by Merrill (1908) from the Philippines, while $P$. kotoensis was described by Hayata (1920) from Lanyu. Psychotria kotoensis was later merged with P. cephalophora (Yang 1998b). Recently, Sohmer and Davis (2007) stated, based on a study of specimens, that $P$. cephalophora from the Philippines and P. kotoensis from Taiwan are not conspecific, but they did not describe differences between the two species. Tao and Taylor (2011) provisionally applied the name P. cephalophora to plants from Lanyu because of the lack of data in Sohmer and Davis (2007). In this study, we tentatively use the name Psychotria cephalophora Merr. for the plants from Lanyu Island. Until now, details of the floral morphology of P. cephalophora have been insufficiently examined (Yang 1998b; Sohmer and Davis 2007; Tao and Taylor 2011). Therefore, more information on the floral morphology of $P$. cephalophora is important in considering the taxonomy of these plants.

In this paper, we present the results of a detailed study of the floral morphology and breeding system, focusing specifically on distyly, of Psychotria cephalophora on Lanyu. We also briefly discuss the evolutionary significance of distyly on Lanyu Island.

\section{Methods}

Study site and sample collection

Psychotria cephalophora on Lanyu grows to $2.5 \mathrm{~m}$ tall. It is terrestrial in relatively dark, wet evergreen forests (Figure 1) and blooms from February to April, according to specimen records. The fruit matures from September to January.

Observations and collections of Psychotria cephalophora were carried out in one natural population at Tienchi Pond (N22 01', E121 34', 337 m a.s.l.). We collected non-flowering branch cuttings on 12 September 2011 and 13 September 2012, and planted them in the greenhouse of Okinawa National College of Technology, Okinawa, Japan. To study sexual and morphological differentiation of flowers, more than two inflorescences per plant were collected from 40 plants from the Tienchi population on 30 March 2013 and preserved in 70\% ethanol.

\section{Measurements and observations of floral morphology}

Ethanol-preserved flowers from the 40 plants were used. We measured the diameter of the inflorescence (Figure $1 \mathrm{Cx}$ ), anther height (Figure 2a), corolla height (Figure 2b), and stigma height (Figure 2c) using two flowers from different inflorescences on each plant, and the number of flowers per inflorescence was determined. The mean values of two flowers were calculated to represent each plant.

In addition to the measurements of the floral traits, we observed floral morphology of $P$. cephalophora both in the field and in the greenhouse.
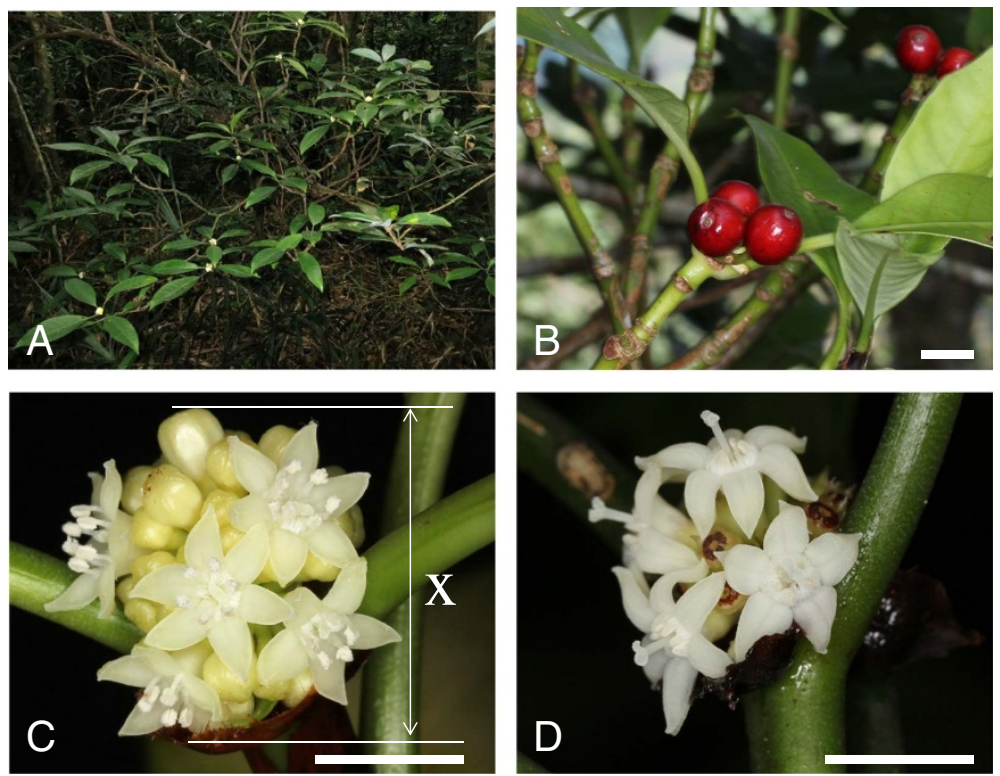

Figure 1 Flowers and fruit of Psychotria cephalophora in the Tienchi population, Lanyu Island, Taiwan. (A) Flowering branches. (B) Young fruit and inflorescences. (C) Short-styled morphs. (D) Long-styled morphs. X, diameter of inflorescence. All scale bars (B-D) $=1 \mathrm{~cm}$. 

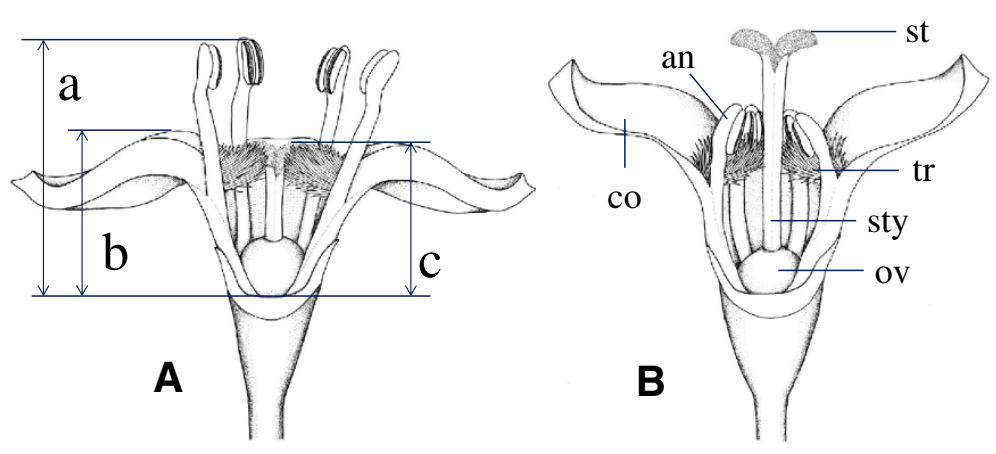

Figure 2 Drawings of short (A) and long-styled (B) flowers from the Tienchi population of Psychotria cephalophora, Lanyu Island, Taiwan. a, anther height; b, corolla height; c, stigma height. an, anther; co, corolla lobe; ov, ovary; st, stigma; sty, style; tr, oblique-facing long hairs. Scale bar $=5 \mathrm{~mm}$.

\section{Pollen size and stainability}

Equatorial and polar diameters of 30 pollen grains from a single flower were measured using a light microscope in 10 plants for each morph. We excluded pollen grains that were extremely small or had irregular shapes. Pollen stainability with aniline blue was determined using 200 pollen grains per flower for 10 plants for each morph to examine pollen viability (Kearns and Inouye 1993). A single anther within a flower before anthesis was crushed on a glass slide with $0.05 \%$ aniline blue (Nakarai esque, Kyoto, Japan) in lactophenol, and counted the number of stained and nonstained pollen grains under light microscope. Two flowers per plant were examined to calculate the mean value.

\section{SEM observations of stigma and pollen}

Fresh stigmas from the two morphs, collected in the greenhouse in April 2013, were observed using environmental scanning electron microscopy (SEM, S-3000 N; Hitachi, Tokyo, Japan). Pollen grains from two morphs were treated by the standard acetolysis method (Erdtman 1960), dehydrated in an ethanol: t-butanol series, freeze-dried using a freeze-drying device (FDU-1000; Eyela, Tokyo, Japan), mounted onto SEM stubs on double sided carbon tape, coated with Pt using an ion sputter coater (E-1010; Hitachi) and observed using SEM (S-3000 N) and Field Emission SEM (S-4800; Hitachi).

\section{Pollination experiments}

To elucidate incompatibility systems by observing pollen tube penetration in the style, intermorphic, intramorphic and self- pollinations were carried out in the greenhouse in April 2013. Approximately 24 h after hand pollination the pistils were collected, fixed in formalin acetic alcohol (FAA) solution (5:5:90= solution of formalin : glacial acetic acid : $70 \%$ ethanol) or $70 \%$ ethanol, and transferred to new $70 \%$ ethanol for storage. The fixed styles were softened in $8 \mathrm{~N} \mathrm{NaOH}$ for $24 \mathrm{~h}$ at $4^{\circ} \mathrm{C}$, rinsed with water and then stained with $0.005 \%$ aniline blue in $\mathrm{Na}_{2} \mathrm{HPO}_{4}(\mathrm{pH} 11)$ for $3 \mathrm{~h}$ at $4^{\circ} \mathrm{C}$ according to (Kearns and Inouye 1993). The styles were mounted on a slide in glycerol beneath a cover glass and gently pressed to spread tissue. Pollen grains on the stigmas and pollen tubes in the styles were observed using a fluorescence light microscope (Axio Imager Z2; Zeiss, Oberkochen, Germany) with U-filter set 49 (Excitation 365 nm, Emission $445 \mathrm{~nm}$; Zeiss).

\section{Statistical analyses}

All statistical tests were performed using $\mathrm{R}$ ver. 3.0.0 software (The R Project for statistical computing; http:// www.r-project.org/).

\section{Results}

\section{Floral morphology and distyly}

The terminal inflorescences were composed of $14-60$ pedicellate flowers in a head-like cluster. The corolla tube, whitish and funnel shaped, averaging about $3 \mathrm{~mm}$ long, was glabrous outside and has white hairs in the throat. The five or six, triangular to oblong corolla lobes were about $3.5 \mathrm{~mm}$ long. All flowers examined had a single style, two ovules per ovary, and five or six anthers. The flowers opened in the morning and lasted until the next morning/noon. They produced a perceptible scent.

Psychotria cephalophora in wild was distylous, with L- and S-styled flowers (Figure 3). Each plant had either S- or L-styled flowers. Measurements of the stigmas and anthers of the two morphs are presented in Table 1 and Figure 4. Anther height was significantly greater in the S-styled morph than in the L-styled morph, while stigma height was significantly less in the S-styled morph than in the L-styled morph (Table 1). No significant difference was found between the morphs (Table 1) in corolla length. No significant difference was found between stigma height of the L-styled morph and anther height of the S-styled morph (Figure 4). Anther height of the L-styled morph was significantly greater than stigma height of the S-styled morph but the difference in mean values was only $0.6 \mathrm{~mm}$ (Table 1 ). Anthers and 


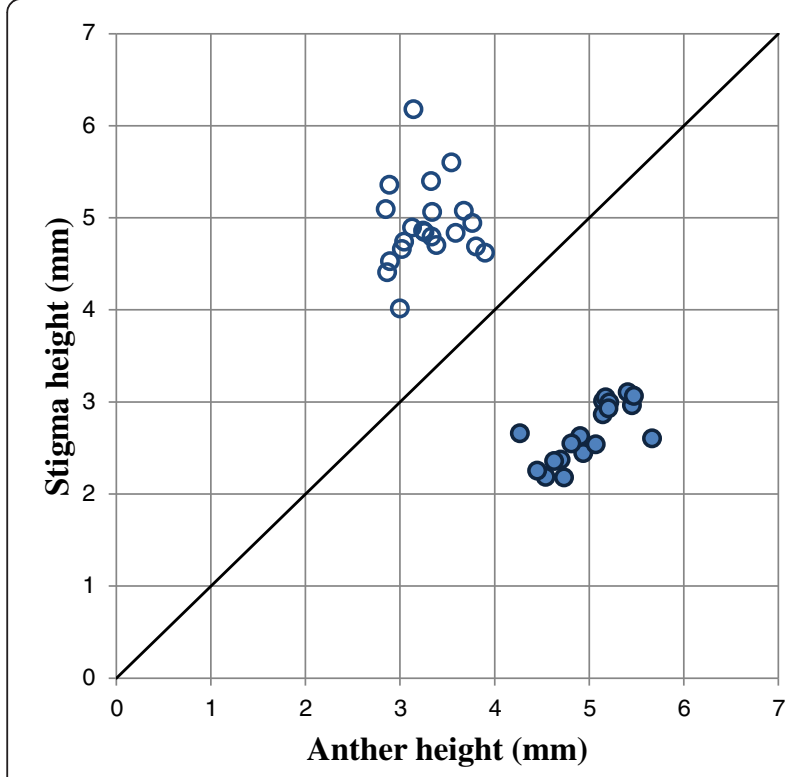

Figure 3 Scatter diagram showing the relationship between stigma and anther heights of Psychotria cephalophora in the Tienchi population. The bold line in a figure is $y=x$, meaning that anther and stigma heights are equal. $\bullet$, a flower of short-styled morph; 0 , a flower of long-styled morph.

stigmas of the different morphs were roughly at the same height. The stigmas were bifurcated and produced welldeveloped stigmatic papillae on both morphs. The fine structures of the stigmatic surface differed between the two morphs. In the S-styled morph the papillae are longer and less crowded than in the L-styled morph (Figure 5).

The inflorescence was $12.9-23.6 \mathrm{~mm}$ in diameter in the S-styled morph and 11.32 - $19.99 \mathrm{~mm}$ in the L-styled morphs. Flowers per inflorescence ranged from $22-57$ in the S-morph and 15 - 37 in the L-styled morph. The size of the inflorescence and the number of flowers per inflorescence were greater in the S-styled morph, but the differences between the two morphs were insignificant (Table 1).

In the Tienchi population, we found 21 L-styled morph individuals and $21 \mathrm{~S}$-styled morph individuals. There was therefore no significant deviation from a 1:1 morph ratio (Binomial test: $p>0.05$ ).

\section{Pollen stainability, size and exine sculpturing}

The pollen grains of Psychotria cephalophora were spherical, had 3 or 4 colpi, and had reticulate exine. Polar axis/ equatorial axis ratio (E/P ratio) of pollen grains was about 1.08 in both morphs. There was no significant difference between the two morphs (Mann Whitney $U$-test; $p>0.05$ ). In addition, we did not notice major differences between the two morphs in exine sculpturing (Figure 6). Pollen size of the two morphs, however, was clearly different. The pollen of the S-styled morph was more than $50 \mu \mathrm{m}$ in diameter and about $10 \mu \mathrm{m}$ larger than in the L-styled morph (Mann Whitney $U$-test; $p<0.001)$. Pollen stainability was over $90 \%$ in both the morphs (Table 2 ).

\section{Pollination experiments}

In intermorph pollinations, more than five pollen tubes reached the base of the style in all the plants (Figure 7; Table 3). In intramorph and self-pollinated flowers, the pollen tubes did not reach the base of the style except for three cases in intramorph pollinations of the L-styled morph and two cases of selfing in the L-styled morph.

\section{Discussion}

\section{Distyly of Psychotria cephalophora on Lanyu Island}

Our observations revealed Psychotria cephalophora to be morphologically and functionally distylous with S- and L- styled morphs. Generally, reciprocal positioning of stamens and anthers of the two morphs is characteristic of distylous species (Barrett 2002), and reciprocal placement of the organs in distylous flowers is considered to promote disassortative pollination (Keller et al. 2014). In P. cephalophora, although stigma height of the S-styled morph is significantly lower than anther height of the L-styled morph (Figure 4), the difference was only $0.6 \mathrm{~mm}$ (Table 1 ). Thus, probably this small gap does not prevent disassortative pollination between the two morphs. Although we did not observe pollinators in natural populations, moths

Table 1 A comparison of several floral traits between Short- and Long-styled morphs of Psychotria cephalophora

\begin{tabular}{|c|c|c|c|c|c|}
\hline & \multicolumn{2}{|c|}{ Short-styled morph } & \multicolumn{2}{|c|}{ Long-styled morph } & \multirow{2}{*}{$\begin{array}{l}\text { Mann Whitney's } \\
U \text { test }\end{array}$} \\
\hline & $\mathrm{N \dagger}$ & Mean \pm S. D. & $\mathrm{N} \dagger$ & Mean \pm S. D. & \\
\hline Inflorescence size (mm) & $20 \S$ & $18.2 \pm 2.36$ & 20 & $16.8 \pm 1.81$ & nsł \\
\hline Number of flowers/inflorescence & $20 \S$ & $32.5 \pm 7.53$ & 20 & $28.1 \pm 5.65$ & nsł \\
\hline Stigma height (mm) & 209 & $2.7 \pm 0.32$ & 20 & $4.9 \pm 0.48$ & $p<0.001$ \\
\hline Anther height (mm) & 209 & $5.0 \pm 0.38$ & 20 & $3.3 \pm 0.32$ & $p<0.001$ \\
\hline Corolla height (mm) & 209 & $3.1 \pm 0.36$ & 20 & $3.2 \pm 0.32$ & nsł \\
\hline
\end{tabular}

$\mathrm{tN}$ : Number of individuals examined.

$\S:$ Two inflorescences on each individual were examined.

ๆ:Two flowers from different inflorescences on each individual were examined.

¥ns: Not significantly differnet between two floral morphs $(p>0.05)$. 


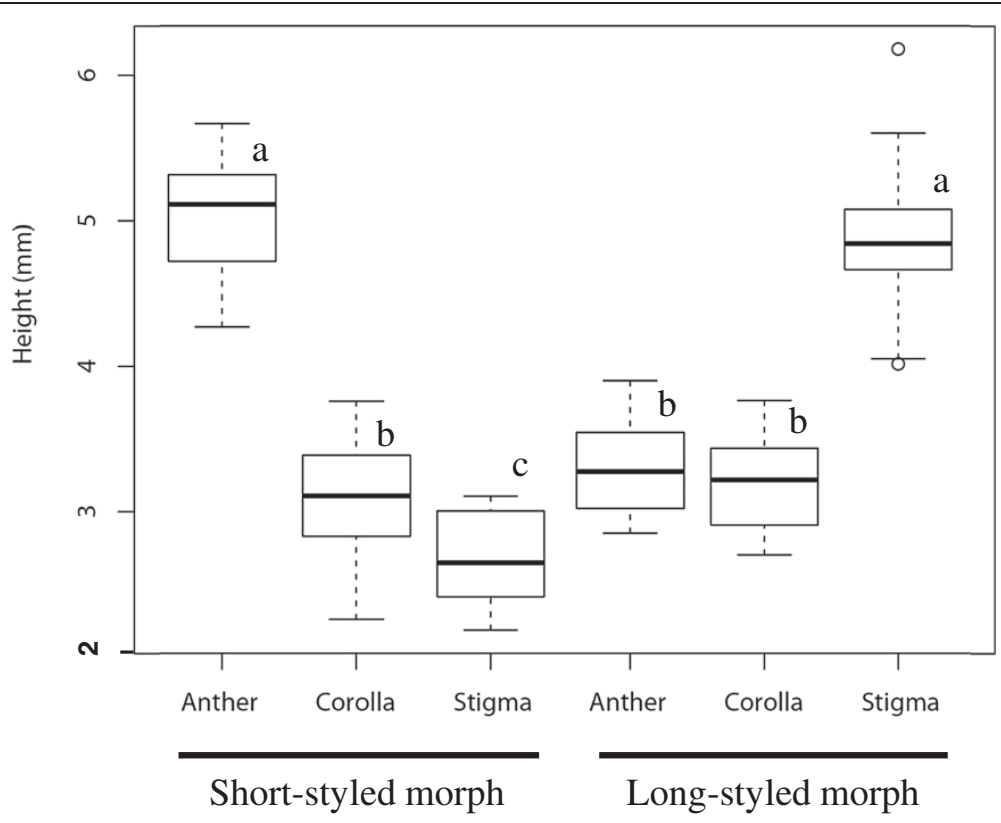

Figure 4 Box plots of three floral traits (anther, corolla and stigma heights) of the short- and long-styled morphs of Psychotria cephalophora. Small letters $(\mathbf{a}, \mathbf{b}, \mathbf{c})$ indicate significant differences at $p<0.001$ determined by Tukey-type multiple comparison after one-way ANOVA.

may be one of the important pollinators because the flowers have a strong scent and white corolla (Van der Pijl 1961). We need to study pollination in natural populations to understand the ecological significance of the positioning of the style and stamens.
The pollen of the S-styled morph is significantly larger than in the L-styled morph (Table 2), a commonly observed phenomenon in distylous species (Ganders 1979). Darwin (1877) suggested that the larger pollen of the S-styled morphs is related to the need for longer


Figure 5 Scanning electron micrographs of stigma of short (A, C) and long-styled (B, D) morphs of Psychotria cephalophora. Scale bars $=200 \mu$ m. 

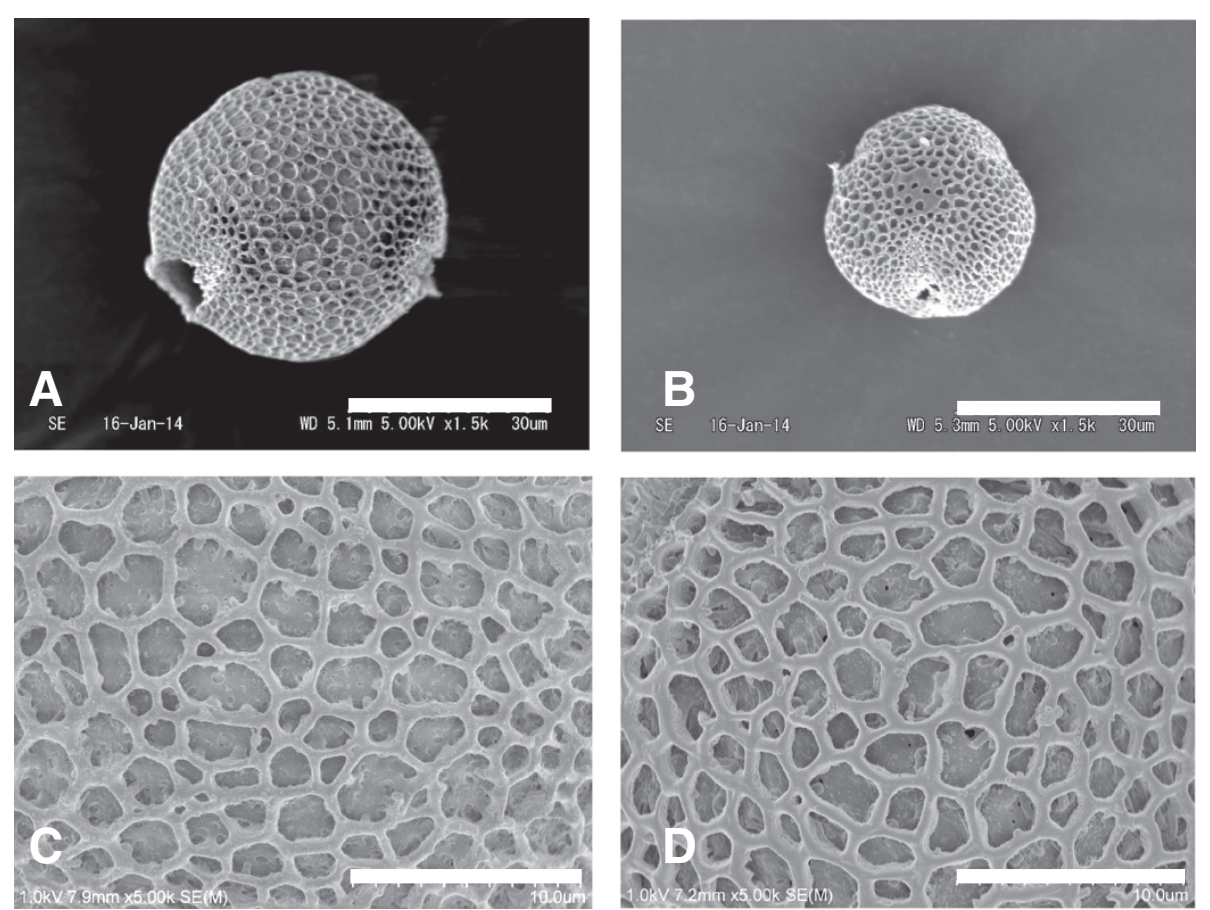

Figure 6 Scanning electron micrographs of pollen grains in short- (A, C) and long-styled (B, D) morphs in Psychotria cephalophora. Scale bars $=30 \mu \mathrm{m}$ (A, B) and $10 \mu \mathrm{m}$ (C, D).

pollen tubes to reach the ovules through the longer styles of the L-styled morph. However, Ganders (1979) found no correlation between L / S style length ratio and $\mathrm{S} / \mathrm{L}$ pollen volume ratio. The adaptive significance of pollen size dimorphism in distylous plants is left to be explored. In P. cephalophora, the pollen exine is reticulated with no distinguishable differences between the two morphs. These features are similar in P. serpens (Sugawara et al. 2013), P. boninensis (Kondo et al. 2007) and P. homalosperma (Watanabe et al. 2014a). Since the stamens of the two morphs produce stainable pollens they are considered to be functional. Meanwhile, both morphs have well developed stigmatic papillae, two ovules per ovary, and frequently set fruit at the study site, indicating that the flowers of both morphs of $P$. cephalophora are hermaphroditic.

In distylous plants, self- and intramorphic incompatibility is commonly observed (Klein et al. 2009). Although we did not test fruit set, hand pollination experiments indicated that $P$. cephalophora is basically self- and intramorphic incompatible (Table 3). However, we also observed a few cases of successful selfand intramorphic pollination in the L-styled morph. This relaxed self- and intramorphic incompatibility in the L-styled morph was also reported for two distylous species of Coussarea and Rudgea (Rubiaceae) by Bawa and Beach (1983), although they reported that those species did not set fruit in the field. To confirm the

Table 2 Pollen size and stainability of Psychotria cephalophora

\begin{tabular}{|c|c|c|c|c|c|}
\hline & \multicolumn{2}{|c|}{ Short-styled morph } & \multicolumn{2}{|c|}{ Long-styled morph } & \multirow{2}{*}{$\begin{array}{l}\text { Mann Whitney's } \\
U \text { test }\end{array}$} \\
\hline & $\mathrm{N \dagger}$ & Mean \pm S. D. & $\mathrm{N \dagger}$ & Mean \pm S. D. & \\
\hline \multicolumn{6}{|l|}{ Pollen size $(\mu \mathrm{m}) \S$} \\
\hline Equatral & 10 & $54.7 \pm 2.5$ & 10 & $44.2 \pm 2.4$ & $p<0.001$ \\
\hline polar & 10 & $50.5 \pm 2.7$ & 10 & $41.1 \pm 2.5$ & $p<0.001$ \\
\hline$E / P$ & 10 & $1.08 \pm 0.03$ & 10 & $1.08 \pm 0.02$ & nsł \\
\hline Pollen stainability (\%)ף & 10 & $93.1 \pm 13.4$ & 10 & $95.9 \pm 2.6$ & nsł \\
\hline
\end{tabular}

$\mathrm{tN}$ : Number of individuals examined.

$\S: 30$ pollen grains from single flowers on each individual were measured.

ๆ: 200 pollen grains from single flowers on each individual were examined.

$\neq n s$ : Not significantly differnet between two floral morphs $(p>0.05)$. 

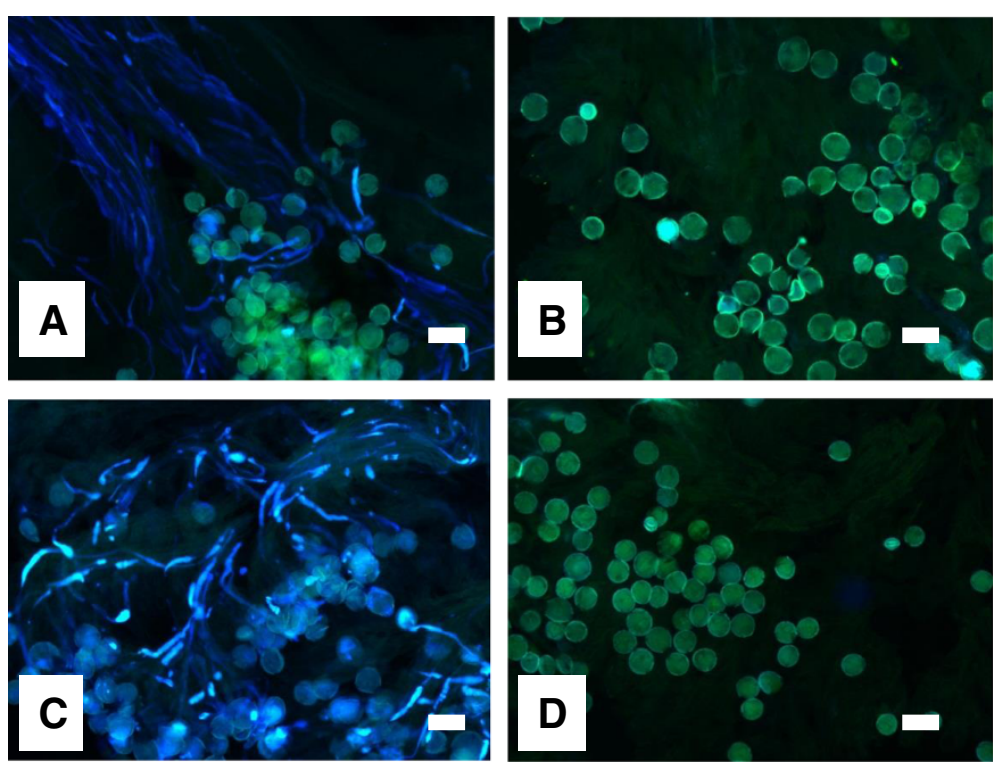

Figure 7 Pollen tubes in pistils approximately $24 \mathrm{~h}$ after intermorphic (A, C) and self- (B, D) pollinations in short- (A, B) and long-styled (C, D) morphs in Psychotria cephalophora observed with fluorescence microscopy. All scale bars $=100 \mu \mathrm{m}$.

compatibility system in P. cephalophora more closely, we also need to examine fruit set after hand pollination experiments. The morph ratio was approximately $1: 1$ in the studied population. This is also typical for distylous plant species, because distyly is a genetically controlled polymorphism following Mendelian inheritance (Barrett and Shore 2008). We did not find any influence of partial self- and intramorphic compatibility in morph ratio.

Recently, many reproductive studies of the genus Psychotria have been performed in neotropics (e. g., Faivre and McDade 2001; Castro et al. 2004; Sakai and Wright 2008). Among them, most species are functionally distylous, but some are intramorphically compatible, and others monomorphic. It is reported that Psychotria carthagenesis in Brazil shows different sexuality among different populations: typical distyly, pin-monomorphism and homostyly (Consolaro et al. 2011; Faria et al. 2012). Since our investigation is restricted only one population of $P$. cephalophora in Lanyu, we need to study more populations to confirm stability of its breeding system.

We described detailed floral morphology of P. cephalophora for the first time. To clarify whether P. cephalophora on Lanyu Island is endemic to the island (as $P$. kotoensis) or conspecific with the species in the Philippines,

Table 3 Pollen tube growth after hand pollination treatments in Psychotria cephalophora

\begin{tabular}{|c|c|c|c|c|c|c|}
\hline \multirow[b]{2}{*}{ Experiments } & \multirow[b]{2}{*}{$\mathrm{n} \neq$} & \multirow[b]{2}{*}{$\mathbf{N} \neq$} & \multicolumn{3}{|c|}{ Status of pollen tube growth } & \multirow{2}{*}{$\begin{array}{l}\text { Percentages of the } \\
\text { pollen tube reached } \\
\text { the base of styles }\end{array}$} \\
\hline & & & $\mathrm{A \S}$ & $B \S$ & $\mathrm{C} \S$ & \\
\hline \multicolumn{7}{|c|}{ Intermorphic pollination } \\
\hline$S \rightarrow L$ cross $t$ & 50 & 7 & 50 & 0 & 0 & $100 \%$ \\
\hline$L \rightarrow S$ cross $t$ & 51 & 8 & 51 & 0 & 0 & $100 \%$ \\
\hline \multicolumn{7}{|c|}{ Intramorphic pollination } \\
\hline SS crosst & 30 & 8 & 0 & 0 & 30 & $0 \%$ \\
\hline LL cross $\dagger$ & 60 & 13 & 3 & 8 & 49 & $5.0 \%$ \\
\hline \multicolumn{7}{|l|}{ Self pollination } \\
\hline St & 77 & 14 & 0 & 2 & 75 & $0 \%$ \\
\hline $\mathrm{L} \dagger$ & 61 & 15 & 2 & 4 & 45 & $3.3 \%$ \\
\hline
\end{tabular}

†S: Short-styled morph; L: Long-styled morph.

$\neq \mathrm{n}$ : Number of flowers examined; N: Number of individuals examined.

$\S A$ : More than five pollen tubes reached at the base of the style.

B: 1 - 10 pollen tubes reached at one third of the style.

C: No pollen tube penetrate into the stigma. 
we need to examine floral traits of $P$. cephalophora in the Philippines. Molecular based analyses would also be useful to solve this issue.

\section{Distyly on the oceanic Lanyu Island}

In this study, we reported distyly in P. cephalophora on the oceanic island Lanyu. Although we are unaware of the exact number of distylous species on Lanyu, there are at least several (e.g., Ophiorrhiza japonica, Liu 1998; Guettarda speciosa, Yang 1998a). In our preliminary observations, $P$. serpens also maintains distyly on Lanyu (Watanabe unpublished data). Distyly is, both theoretically and actually, rare or absent in oceanic islands (Carlquist 1974; Pailler et al. 1998; Meeus et al. 2011; McMullen 2012; Sugawara et al. 2014; Watanabe et al. 2014a). Thus it is of great interest to study how $P$. cephalophora colonized and reproduces on the oceanic island. Self-incompatible plants are thought to be less successful in colonization to oceanic islands than self-fertilizers (Baker 1955; Stebbins 1957; Barrett et al. 1996); self-fertilizers can establish populations from single individual and reproduce successfully without suitable pollinators (Baker 1955; Baker and Cox 1984; Barrett et al. 1996). In general, island florae have higher ratio of hermaphroditic self-compatible plants than in mainland (Crawford et al. 2011). Lanyu and northern islands of the Philippines, where P. cephalophora occurs, have not been land-connected but only a few hundred $\mathrm{km}$ away from each other and these islands share many floristic elements (Nakamura and Kokubugata 2014). Colonization of $P$. cephalophora into Lanyu may have occurred repeatedly unlike more isolated oceanic islands. Also Lanyu is only $60 \mathrm{~km}$ away from Taiwan Island and this is probably why the island has entomofauna rich enough to support self-incompatible distylous plants. There are contradictory cases where oceanic islands have a high proportion of dioecism (Carlquist 1974; Baker and Cox 1984; Sakai et al. 1995; Abe 2006). It is possibly because outcrossing has a merit to avoid inbreeding depressions in small populations on oceanic islands (Sakai et al. 1995; Barrett et al. 1996). Tseng et al. (2008) reported the proportion of dioecism on Lanyu to be very high $(11.9 \%)$ compared to the global average (6\%; Renner and Ricklefs 1995) and Taiwan proper (7.9\%). The outcrossing-merit hypothesis may also be applicable to distyly on Lanyu. To understand how P. cephalophora colonized and reproduces in natural populations, phylogeographic analyses and pollinator observations and testing open fruit sets are required.

\section{Conclusions}

We described detailed floral morphology and incompatibility of Psychotria cephalophora on Lanyu for the first time. Floral dimorphism and intramorphic incompatibility indicate that the breeding system of $P$. cephalophora is morphologically and functionally distylous. Because distyly is usually rare on oceanic islands, it is important to clarify how this species colonized and reproduces on islands. Further reproductive studies of $P$. cephalophora in the natural populations on Lanyu and the Philippines are needed.

\section{Competing interests}

The authors declare that they have no competing interests.

\section{Authors' contributions}

Collection of flower samples: KW, AY, CN, TLH, KN, TS, CIP. Flower Drawing: CN, KW. Morphological study: KW, CN, TS. Draft preparation: KW, TS. Paper writing: KW, TS, KN. All authors read and approved the final manuscript.

\section{Acknowledgements}

We thank Mr. CF. Chen for helping in the field study, Dr. D. Boufford for improving the English, and Drs. H. X. Chiura, M. Hara, N. Ogawa, K. Kogure and $\mathrm{Y}$. Watanabe for their help in using the FE-SEM at the Atmosphere and Ocean Research Institute of the University of Tokyo. This study was partly supported by a Grant -in -Aid for Scientific Research (no. 23923008; 24923009; 26840130 to KW and no. 22570096 to TS).

\section{Author details}

'Okinawa National College of Technology, 905 Henoko, Nago, Okinawa 905-2192, Japan. ${ }^{2}$ Department of Botany, National Museum of Natural Science, Kuan Chien Rd, Taichung 404, Taiwan. ${ }^{3}$ Department of Life Science, National Chung Hsin University, Taichung 402, Taiwan. ${ }^{4} 774-1-302$, Umusa, Nago, Okinawa 905-0006, Japan. ${ }^{5}$ Botanic Garden, Field Science Center for Northern Biosphere, Hokkaido University, North 3, West 8, Chuo-ku, Sapporo 060-0003, Japan. ${ }^{6}$ Biodiversity Research Center, Academia Sinica, Taipei, Nangang 115, Taiwan. ${ }^{7}$ Makino Herbarium, Graduate School of Science, Tokyo Metropolitan University, 1-1 Minami-Ohsawa, Hachioji, Tokyo 192-0397, Japan.

Received: 15 December 2014 Accepted: 28 April 2015 Published online: 07 May 2015

\section{References}

Abe T (2006) Threatened pollination systems in native flora of the Ogasawara (Bonin) Islands. Ann Bot 98:317-334, doi:10.1093/aob/mcl117

Baker HG (1955) Self-compatibility and establishment after longdistance'dispersal. Evolution 9:347-349

Baker HG, Cox PA (1984) Further thoughts on dioecism and islands. Ann Missouri Bot Gard 71:244-253

Barrett SCH (2002) The evolution of plant sexual diversity. Nat Rev Genet 3:274-284, doi:10.1038/nrg776

Barrett SCH, Shore JS (2008) New insights on heterostyly: comparative biology, ecology and genetics. In: Self-incompatibility in Flowering Plants. Springer, Berlin Heidelberg, pp 3-32

Barrett SCH, Emerson B, Mallet J (1996) The reproductive biology and genetics of island plants. Philos Trans R Soc Lond B Biol Sci 351:725-753, doi:10.1098/ rstb.1996.0067

Barrett SCH, Jesson LK, Baker AM (2000) The evolution and function of stylar polymorphisms in flowering plants. Ann Bot 85:253-265, doi:10.1006/ anbo.1999.1067

Bawa KS, Beach JH (1983) Self-incompatibility systems in the Rubiaceae of a tropical lowland wet forest. Am J Bot 70:1281-1288

Carlquist S (1974) Island biology. Columbia Univ Press, New York \& London

Castro CC, Oliveira PE AM, Alves MC (2004) Breeding system and floral morphometry of distylous Psychotria L. species in the Atlantic rain forest, SE Brazil. Plant Biol 6:755-760, doi:10.1055/s-2004-830349

Chen TY, Lu DH (2008) The Inventory of Vascular Plant of Green Island. Construction and Planning Agency, Ministry of the Interior Research Project Report, Taipei

Consolaro H, Silva SCS, Oliveira PE (2011) Breakdown of distyly and pinmonomorphism in Psychotria carthagenensis Jacq. (Rubiaceae). Plant Species Biol 26:24-32, doi:10.1111/j.1442-1984.2010.00300.x

Crawford DJ, Anderson GJ, Bernardello G (2011) The reproductive biology of island plants. In: Barmwell D, Caujape-Castells J (eds) The Biology of Island floras. Cambridge University Press, Cambridge, pp 11-36 
Darwin C (1877) The different forms of flowers on plants of the same species. John Murray, London

Davis AP, Bridson D, Jarvis C, Govaerts R (2001) The typification and characterization of the genus Psychotria L. (Rubiaceae). Bot J Linn Soc 135:35-42, doi:10.1111/j.1095-8339.2001.tb02366.x

Davis AP, Govaerts R, Bridson DM, Ruhsam M, Moat J, Brummitt N (2009) A globa assessment of distribution, diversity, endemism, and taxonomic effort in the Rubiaceae. Ann Missouri Bot Gard 96:68-78, doi:10.3417/2006205

Erdtman G (1960) The acetolysis method. Sven Bot Tidskr 54:561-564

Faivre AE, McDade LA (2001) Population-level variation in the expression of heterostyly in three species of Rubiaceae: does reciprocal placement of anthers and stigmas characterize heterostyly? Am J Bot 88:841-853

Faria RR, Ferrero V, Navarro L, Araujo AC (2012) Flexible mating system in distylous populations of Psychotria carthagenensis Jacq. (Rubiaceae) in Brazilian Cerrado. Plant Syst Evol 298:619-627, doi:10.1007/s00606-011-0571-7

Ganders FR (1979) The biology of heterostyly. New Zeal J Bot 17:607-635

Hamilton CW (1989) A revision of mesoamerican Psychotria subgenus Psychotria (Rubiaceae), part I: introduction and species 1-16. Ann Missouri Bot Gard 76:67-111

Hamilton CW (1990) Variations on a distylous theme in Mesoamerican Psychotria subgenus Psychotria (Rubiaceae). Mem NY Bot Gard 55:62-75

Hayata B (1920) Psychotria kotoensis. In: Icones Plant. Formosanarum nec non Contrib. ad Floram Formosanum. 9. Bureau of productive industry, Government of Formosa, Taipei, p 62

Kearns CA, Inouye DW (1993) Techniques for pollination biologists. University Press of Colorado, Colorado

Keller B, Thomson J, Conti E (2014) Heterostyly promotes disassortative pollination and reduces sexual interference in Darwin's primroses: evidence from experimental studies. Funct Ecol 28:1413-1425, doi:10.1111/1365-2435.12274

Klein DE, Freitas L, Da Cunha M (2009) Self-incompatibility in a distylous species of Rubiaceae: is there a single incompatibility response of the morphs? Sex Plant Reprod 22:121-131, doi:10.1007/s00497-009-0097-0

Kondo Y, Nishide M, Watanabe K, Sugawara T (2007) Floral dimorphism in Psychotria boninensis Nakai (Rubiaceae) endemic to the Bonin (Ogasawara) Islands. J Jap Bot 82:251-258

Liu HY (1998) Ophiorrhiza. In: Huang TC (ed) Flora of Taiwan 4, 2nd edn. Editorial Committee, Dept. Bot., NTU, Taipei, pp 306-311

McMullen CK (2012) Pollination of the heterostylous Galápagos native, Cordia lutea (Boraginaceae). Plant Syst Evol 298:569-579, doi:10.1007/s00606-011-0567-3

Meeus S, Jacquemyn H, Honnay O, Pailler T (2011) Self-incompatibility and pollen limitation in the rare tristylous endemic Hugonia serrata on La Réunion Island. Plant Syst Evol 292:143-151, doi:10.1007/s00606-010-0400-4

Merrill ED (1908) Psychotria cephalophora. Philipp J Sci 3:438

Naiki A (2012) Heterostyly and the possibility of its breakdown by polyploidization. Plant Species Biol 27:3-29, doi:10.1111/j.1442-1984.2011.00363.x

Nakamura K, Kokubugata G (2014) In situ glacial survival at the northern limit of tropical insular Asia by a lowland herb Begonia fenicis (Begoniaceae). Bot J Linn Soc 174:305-325, doi:10.1111/boj.12138

Nepokroeff M, Bremer B, Sytsma KJ (1999) Reorganization of the genus Psychotria and tribe Psychotrieae (Rubiaceae) inferred from ITS and rbcL sequence data. Syst Bot 24:5-27

Pailler T, Humeau L, Thompson JD (1998) Distyly and heteromorphic incompatibility in oceanic island species of Erythroxylum (Erythroxylaceae). Plant Syst Evol 213:187-198, doi:10.1007/BF00985199

Renner SS, Ricklefs RE (1995) Dioecy and its correlates in the flowering plants. Am J Bot 82:596-606

Sakai S, Wright J (2008) Reproductive ecology of 21 coexisting Psychotria species (Rubiaceae): when is heterostyly lost? Biol I Linn Soc 93:125-134, doi:10.1111/j.1095-8312.2007.00890.x

Sakai AK, Wagner WL, Ferguson DM, Herbst DR (1995) Origins of dioecy in the Hawaiian flora. Ecology 76:2517-2529

Sohmer SH, Davis AP (2007) The genus Psychotria (Rubiaceae) in the Philippine Archipelago. Sida, Botanical Miscellany, vol 27. Botanical Research Institute of Texas, Texas

Stebbins GL (1957) Self fertilization and population variability in the higher plants. Am Nat 91:337-354

Sugawara T, Watanabe K, Tabata M (2013) Distyly in Psychotria serpens (Rubiaceae) in the Ryukyu Islands, Japan. Acta Phytotax Geobot 64:113-122

Sugawara T, Yumoto T, Tsuneki S, Watanabe K (2014) Incompatibility and reproductive output in distylous Psychotria boninensis (Rubiaceae), endemic to the Bonin (Ogasawara) Islands, Japan. J Jap Bot 89:22-26
Tao C, Taylor CM (2011) Psychotria. In: Chen T, Taylor CM, Swartz C (eds) Flora of China, vol 19. Science Press and Missouri Botanical Garden Press, Beijing and St. Louis, pp 294-301

Tsai C-C (2009) A study on flora of Kushan Island. Master's thesis. Providence University, Taichung

Tseng YH, Hsieh CF, Hu JM (2008) Incidences and ecological correlates of dioecious angiosperms in Taiwan and its outlying Orchid Island. Bot Stud 49:261-276

Van der Pijl L (1961) Ecological aspects of flower evolution. II. Zoophilous flower classes. Evolution (N Y) 15:44-59

Watanabe K, Kato H, Sugawara T (2014a) Distyly and incompatibility in Psychotria homalosperma (Rubiaceae), an endemic plant of the oceanic Bonin (Ogasawara) Islands. Flora 209:641-648, doi:10.1016/j.flora.2014.09.006

Watanabe K, Shimizu A, Sugawara T (2014b) Dioecy derived from distyly and pollination in Psychotria rubra (Rubiaceae) occurring in the Ryukyu Islands, Japan. Plant Species Biol 29:181-191, doi:10.1111/1442-1984.12013

Yang TYA (1998a) Guettarda. In: Huang TC (ed) Flora of Taiwan 4, 2nd edn. Editorial Committee, Dept. Bot., NTU, Taipei, p 263

Yang TYA (1998b) Psychotria. In: Huang TC (ed) Flora of Taiwan 4, 2nd edn. Editorial Committee, Dept. Bot., NTU, Taipei, pp 315-318

Yang YP, Liu HY, Shih BL, Lu SY (1999) Rubiaceae. In: Yang YP, Liu HY, Shih BL, Lu SY (eds) Man. Taiwan Vasc, PI, vol 4. The Council of Agriculture, Taipei, pp 74-99

\section{Submit your manuscript to a SpringerOpen ${ }^{\odot}$ journal and benefit from:}

- Convenient online submission

- Rigorous peer review

- Immediate publication on acceptance

- Open access: articles freely available online

- High visibility within the field

- Retaining the copyright to your article

Submit your next manuscript at $\gg$ springeropen.com 